\title{
Efficacy of Physiotherapy and Conductive Education in Improving Motor Skills and Mental Function in Children with Cerebral Palsy
}

\author{
Sara Hamdy Mohamed', Saneya Abd El Halim Fahmy², Amal Gaber Mohamed², \\ Mohamed Hossam El-Sabbagh ${ }^{1}$ \\ ${ }^{1}$ National Institute of Neuromotor System, Cairo, Egypt \\ ${ }^{2}$ Faculty of Medicine for Girl, Al-Azhar University, Cairo, Egypt \\ Email: doctorasaraa@gmail.com, saneyafahmy@yahoo.com, amalgaber_33@yahoo.com, Mohamed_h5@gmail.com
}

How to cite this paper: Mohamed, S.H., E Halim Fahmy, S.A., Mohamed, A.G. and El-Sabbagh, M.H. (2020) Efficacy of Physiotherapy and Conductive Education in Improving Motor Skills and Mental Function in Children with Cerebral Palsy. Open Journal of Pediatrics, 10, 369-380.

https://doi.org/10.4236/ojped.2020.102038

Received: May 31, 2020

Accepted: June 27, 2020

Published: June 30, 2020

Copyright $\odot 2020$ by author(s) and Scientific Research Publishing Inc. This work is licensed under the Creative Commons Attribution International License (CC BY 4.0).

http://creativecommons.org/licenses/by/4.0/ (c) (i) Open Access

\begin{abstract}
Background: Children with Cerebral Palsy (CP) often receive physiotherapy to achieve maximum motor potential and prevent secondary conditions. Conductive Education (CE) is an education programme that combines special education and rehabilitation. Purpose: Study the effect of physiotherapy and conductive education in development of fine, gross motor skills and mental function in the children with CP. Subjects and Methods: This is a prospective case study that was carried out on 105 children with CP less than 4 years old selected from outpatient clinic in National Institute for Neuro Motor System. Cases were taken consecutively from February 2019 to September 2019. A written informed consent was taken from all participants after proper explanation of the study. They were classified into three groups (group I, group II and group III) according to their age. All children are subjected to complete history taking, clinical examination, use of developmental quotient (DQ) sheet before and after 6 months of regular physiotherapy and conductive education program. Results: There was statistically significant improvement in fine motor, cognation and gross motor in 3 groups after 6 months of regular physiotherapy and conductive education program. The maximum improvement was in group I, so children with cerebral palsy were achieved maximum improvement when physiotherapy and conductive education started as early as possible. Conclusion: Significant improvement has in fine motor, cognation and gross motor in 3 groups after 6 months of regular physiotherapy and conductive education program. Early start physiotherapy and conductive education program gave us better outcome.
\end{abstract}




\section{Keywords}

Cerebral Palsy, Conductive Education, Rehabilitation

\section{Introduction}

Cerebral palsy (CP) is a neurological condition which can affect people in different ways, resulting in different types and levels of impairment(s). Cerebral Palsy may occur at birth where specific parts of the brain have been damaged as a result of a medical complication(s) [1].

It is not possible to diagnose $\mathrm{CP}$ in infants less than 6 months except in very severe cases. The patterns of various forms of $\mathrm{CP}$ emerge gradually with the earliest clues being a delay in developmental milestones and abnormal muscle tone [2].

Physiotherapy has long been central to the clinical management of children with these disorders. Children are often referred to physiotherapy as soon as the diagnosis is confirmed or suspected [3].

\section{Aim of Work}

Study the effect of physiotherapy and conductive education in development of fine, gross motor skills and mental function in the children with cerebral palsy.

\section{Subjects and Methods}

Subjects: The protocol was approved by the local research ethics committee of the pediatric department at Al-Azhar University for girls and a written informed consent was taken from all participants after proper explanation of the study.

This is a prospective case study that was carried out on 105 children with cerebral palsy less than 4 year selected from outpatient clinic of pediatric neurology department in National Institute for Neuro Motor System; cases were taken consecutively from February 2019 to September 2019; the inclusion criteria were conducted in the study.

\section{Inclusion criteria:}

1) Spastic cerebral palsy children (paraplegic, diplegic, hemiplegic) and atonic cerebral palsy which diagnosed by pediatric neurologist.

2) Patient should have educable and cooperative function allowing for physiotherapy.

3) Both sexes.

\section{Exclusion criteria:}

1) Both newly diagnosed and old cases. Dyskinatic and ataxic cerebral palsy children.

2) Severe behavioral disorder that could interfere with physiotherapy.

3) Other concomitant neurologic disorder or neurodegenerative disorder or muscle-skeletal disorder. 


\section{4) Profound mental retardation}

\section{Method:}

During the period of the study any child come to outpatient clinic less than 4 years old hislher parent complained of delayed this child motor, mental or the child has history of any problem happened prenatal, natal and postnatal were subjected to the following: complete history taking with special emphasis on: 1) Personal history (Full Name, birth date, age by months, sex and residence), complain, medical history (History: prenatal, perinatal, postnatal, history of maternal illness or infection during pregnancy, History of admission in NICU, The presence of co-morbid conditions like visual, hearing impairment, epilepsy, speech and behaviour abnormalities), family history, drug history and physiotherapy history. 2) Clinical examinations, complete neurological examination and assessment as motor power and tone of the muscle in upper limp and lower limp, reflexes (superficial, deep, and pathological reflex), examination of the sensory system, ask about sphincteric control to the urine and stool.

If diagnosed cerebral palsy by pediatric neurologist and fulfill all inclusion criteria, we Used of Developmental quotient (DQ) sheet: The DQ has been performed twice to the patient 1 st before starting in physiotherapy and conductive education and the 2nd one after 6 months of regular of physiotherapy and rehabilitation program then we compared between two. Scores on these developmental scales were used to calculate a developmental quotient (DQ) according to the formula: $\mathrm{DQ}=$ (months corresponding to test performance) $\times 100 /$ (the child's chronological age in months)

The scores is take from text book called Developmental Programming for Infants and Young Children Designed by (University of Michigan Press ELT, 1981) for children functioning in the 0-to-36-month developmental age range, this score sheet is designed to permit small increments in a child's skills to be frequently noted and a child's development to be graphically displayed.

\section{Results}

After the text edit has been completed, the paper is ready for the template. Duplicate the template file by using the Save As command, and use the naming convention prescribed by your journal for the name of your paper. In this newly created file, highlight all of the contents and import your prepared text file. You are now ready to style your paper.

Table 1 and Figure 1, Figure 2: demonstrate the demographic data (age, sex and consanguinity) of cerebral palsy children. The age was classified as following (group I any child diagnosed as CP his \her age less than 12 months, group II ranged between 13 months to 23 months and group III ranged between 24 months to 48 months.

The male was predominant represented $58.03 \%$ while the female represented $41.9 \%$.

The negative consanguinity was predominant represented $68 \%, 1 \%$ and $58 \%$ respectively in the 3 groups. 


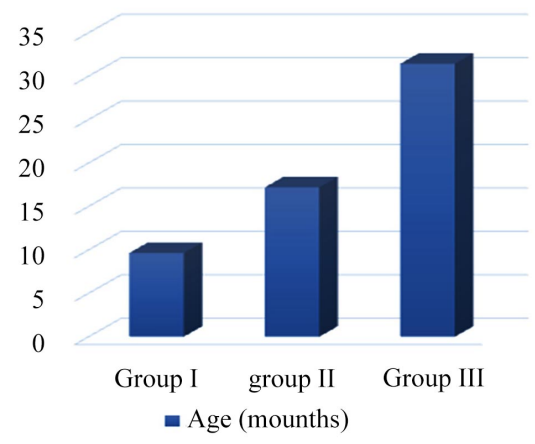

Figure 1. Age in 3 groups.

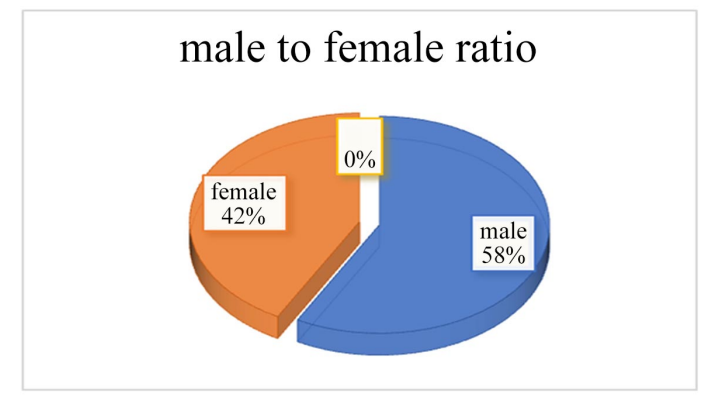

Figure 2. Male to female ratio.

Table 1. Comparison between group I, group II and group III regards demographic data.

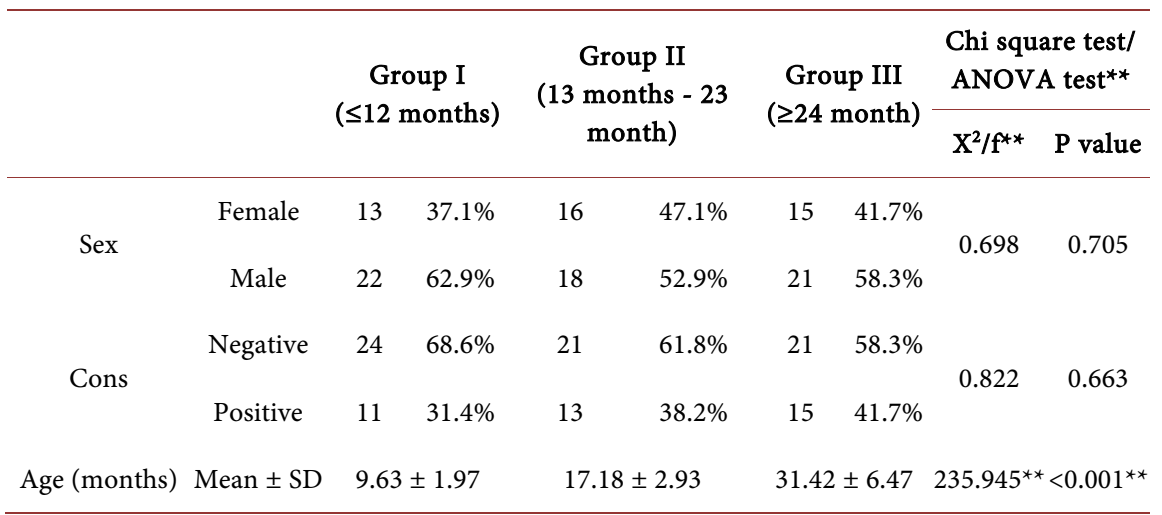

Table 2 and Figure 3: demonstrate according to the natal and post-natal history, the largest percentage in risk factor in the 3 groups was a history of incubated by respiratory distress that shown $51 \%$ in a group I, $35 \%$ in a group II and $33 \%$ in a group III. $6 \%$ in a group I, $15 \%$ in a group II and $6 \%$ in group III.

Table 3 and Figure 4: illustrate the clinical picture and fits in the 3 group. Showing $77 \%$ of group I, $85 \% \ldots$ of $\ldots$ group II and $75 \% \ldots$ of group III presented by spastic cerebral palsy. In comparison of 3 groups according to associated fits it was positive or present in $37 \%$ in a group I, $12 \%$ in a group II and $14 \%$ in a group III

Table 4 and Figure 5 show there was statistically significant improvement in fine motor, cognation and gross motor in group I, II and III after 6 months of 
regular physiotherapy and conductive education program. There was statistically significant increase in improvement in group I in comparison to group II and group III by use developmental quotient before and after 6 months of physiotherapy and conductive education session.

Table 5 and Figure 6 show there is a significant improvement in fine motor, cognation and gross motor in children with cerebral palsy when start physiotherapy a conductive education early as possible.

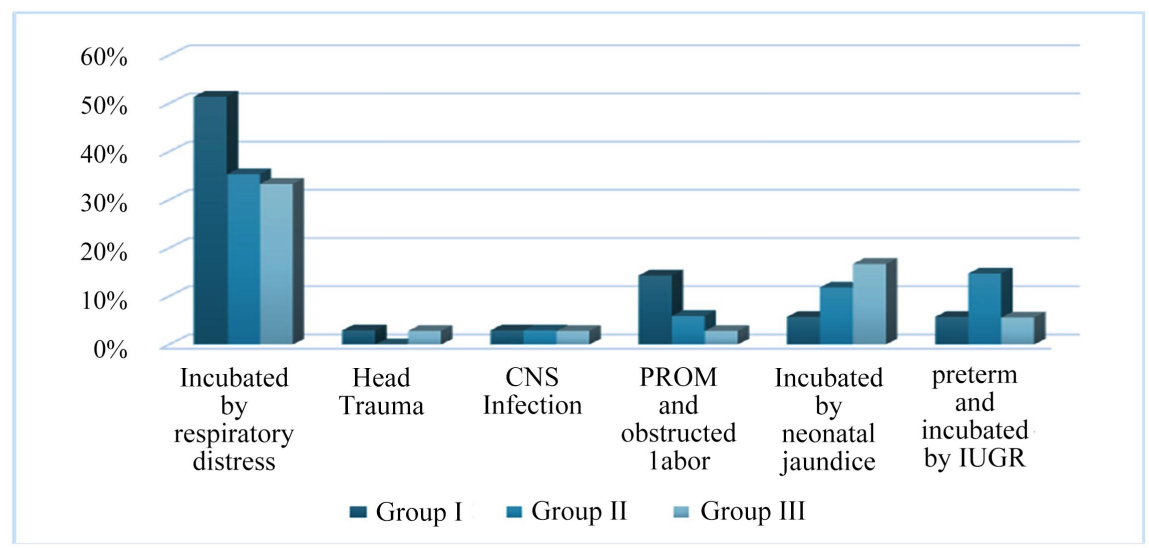

Figure 3. Risk factors of cerebral palsy children.

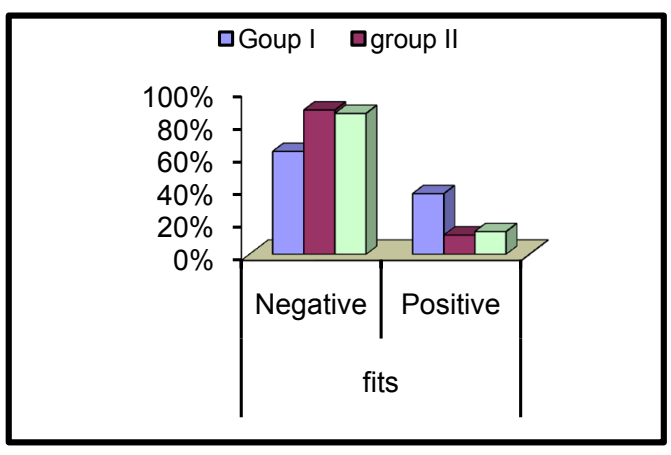

Figure 4. Fits in cerebral palsy children.

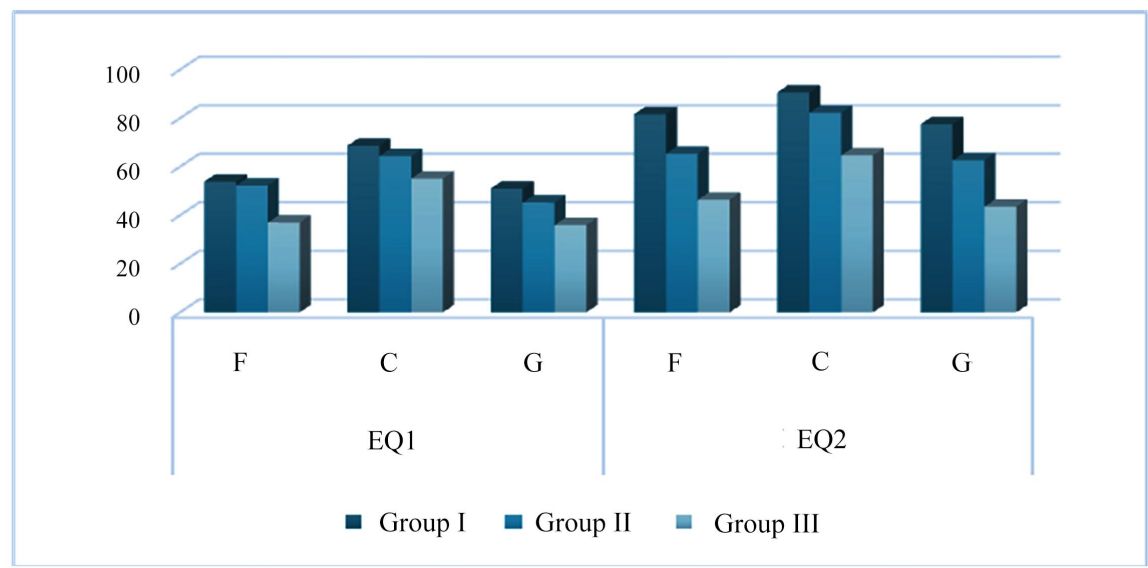

Figure 5. Developmental quotient results before starting physiotherapy and conductive education session and 6 months after this session in group I, II and III. 


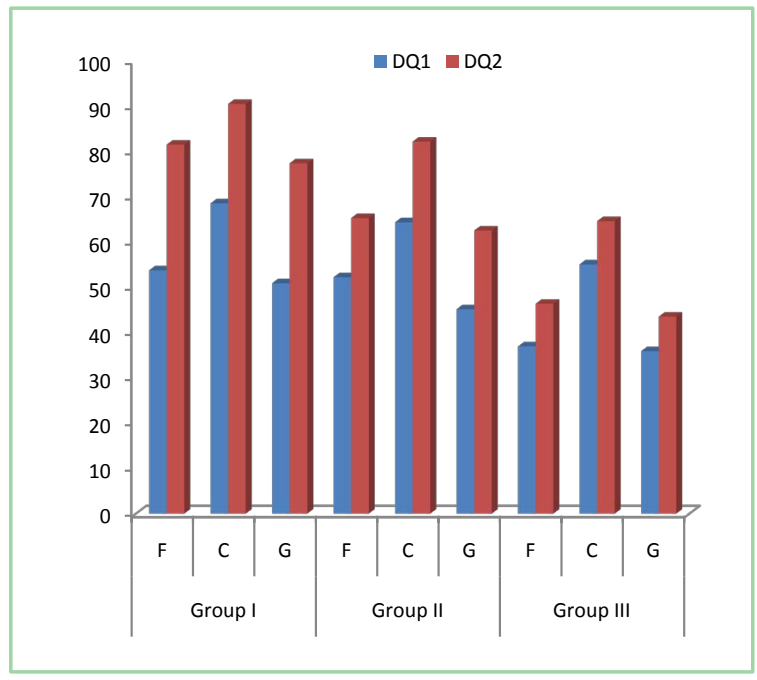

Figure 6. Improvement in fine motor, cognation and gross motor in children with cerebral palsy.

Table 2. Comparison between group I, group II and group III as regarding the risk factors.

\begin{tabular}{ccccccccc}
\hline & \multicolumn{2}{c}{$\begin{array}{c}\text { Group I } \\
(\leq 12 \mathrm{~ms})\end{array}$} & $\begin{array}{c}\text { group II } \\
(\mathbf{1 3} \mathrm{ms}-\mathbf{2 3} \mathrm{ms})\end{array}$ & $\begin{array}{c}\text { Group III } \\
(\geq 24 \mathrm{~ms})\end{array}$ & \multicolumn{2}{c}{ Chi square test } \\
\cline { 2 - 9 } & No & $\%$ & No & $\%$ & No & $\%$ & $\mathrm{X}^{2}$ & P value \\
\hline $\begin{array}{c}\text { History of Incubation by } \\
\text { respiratory distress }\end{array}$ & 18 & $51.4 \%$ & 12 & $35.3 \%$ & 12 & $33.3 \%$ & 2.885 & 0.236 \\
$\quad \begin{array}{c}\text { Head Trauma } \\
\text { CNS Infection }\end{array}$ & 1 & $2.9 \%$ & 0 & $0.0 \%$ & 1 & $2.8 \%$ & 0.977 & 0.614 \\
$\begin{array}{c}\text { PROM and } \\
\text { obstructed labor }\end{array}$ & 1 & $2.9 \%$ & 1 & $2.9 \%$ & 1 & $2.8 \%$ & 0.002 & 0.999 \\
$\begin{array}{c}\text { Incubated by } \\
\text { neonatal jaundice }\end{array}$ & 2 & $14.3 \%$ & 2 & $5.9 \%$ & 1 & $2.8 \%$ & 3.555 & 0.169 \\
$\begin{array}{c}\text { Prematurity incubated by } \\
\text { IUGR }\end{array}$ & 2 & $5.7 \%$ & 4 & $11.8 \%$ & 6 & $16.7 \%$ & 2.109 & 0.348 \\
\hline
\end{tabular}

Table 3. Comparison between group I, group II and group III as regards clinical picture and fits. and fits.

\begin{tabular}{|c|c|c|c|c|c|c|c|c|c|}
\hline & & \multicolumn{2}{|c|}{$\begin{array}{l}\text { Group I } \\
(\leq 12 \mathrm{~ms})\end{array}$} & \multicolumn{2}{|c|}{$\begin{array}{c}\text { group II } \\
(13 \mathrm{~ms}-23 \mathrm{~ms})\end{array}$} & \multicolumn{2}{|c|}{$\begin{array}{l}\text { Group III } \\
(\geq 24 \mathrm{~ms})\end{array}$} & \multicolumn{2}{|c|}{$\begin{array}{c}\text { chi square } \\
\text { test }\end{array}$} \\
\hline & & No & $\%$ & No & $\%$ & No & $\%$ & $x^{2}$ & $\mathrm{p}$ value \\
\hline \multirow{5}{*}{$\mathrm{CL} / \mathrm{p}$} & Atonic & 8 & $22.9 \%$ & 5 & $14.7 \%$ & 9 & $25.0 \%$ & \multirow{2}{*}{1.234} & \multirow{2}{*}{0.540} \\
\hline & Spastic & 27 & $77.1 \%$ & 29 & $85.3 \%$ & 27 & $75.0 \%$ & & \\
\hline & - Diplegic & 18 & $66.7 \%$ & 21 & $72.4 \%$ & 22 & $81.5 \%$ & \multirow{3}{*}{0.893} & \multirow{3}{*}{0.925} \\
\hline & - Hemiplegic & 6 & $22.2 \%$ & 7 & $24.1 \%$ & 5 & $18.5 \%$ & & \\
\hline & - Quadriplegic & 3 & $11.1 \%$ & 2 & $6.9 \%$ & 2 & $7.4 \%$ & & \\
\hline \multirow{2}{*}{ Fits } & Negative & 22 & $62.9 \%$ & 30 & $88.2 \%$ & 31 & $86.1 \%$ & \multirow{2}{*}{8.357} & \multirow{2}{*}{0.015} \\
\hline & Positive & 13 & $37.1 \%$ & 4 & $11.8 \%$ & 5 & $13.9 \%$ & & \\
\hline
\end{tabular}


Table 4. Comparison in developmental quotient results before starting physiotherapy and conductive education session and 6 months after this session in group I, II and III.

\begin{tabular}{|c|c|c|c|c|c|c|c|c|c|}
\hline & & \multicolumn{2}{|c|}{$\begin{array}{l}\text { Group I } \\
(\leq 12 \mathrm{~ms})\end{array}$} & \multicolumn{2}{|c|}{$\begin{array}{l}\text { Group II } \\
(13 \mathrm{~ms}-23 \mathrm{~ms})\end{array}$} & \multicolumn{2}{|c|}{$\begin{array}{l}\text { Group III } \\
(\geq 24 \mathrm{~ms})\end{array}$} & \multicolumn{2}{|c|}{$\begin{array}{l}\text { One way } \\
\text { ANOVA }\end{array}$} \\
\hline & & Mean & SD & Mean & $\mathrm{SD}$ & Mean & SD & F & $\mathrm{p}$ value \\
\hline $\begin{array}{l}\text { Developmental } \\
\text { quotient result }\end{array}$ & $\begin{array}{l}\text { Fine } \\
\text { motor }\end{array}$ & $53.74 \%$ & $18.53 \%$ & $62.21 \%$ & $19.78 \%$ & $36.94 \%$ & $18.29 \%$ & 8.452 & $<0.001$ \\
\hline $\begin{array}{l}\text { before starting } \\
\text { physiotherapy and }\end{array}$ & Cognition & $68.54 \%$ & $621.59 \%$ & $64.35 \%$ & $20.55 \%$ & $55.06 \%$ & $22.11 \%$ & 3.686 & 0.028 \\
\hline $\begin{array}{l}\text { conductive } \\
\text { education session }\end{array}$ & $\begin{array}{l}\text { Gross } \\
\text { motor }\end{array}$ & $50.89 \%$ & $621.66 \%$ & $65.15 \%$ & $20.76 \%$ & $35.88 \%$ & $17.86 \%$ & 4.846 & 0.001 \\
\hline $\begin{array}{l}\text { Developmental } \\
\text { quotient result } 6\end{array}$ & $\begin{array}{l}\text { Fine } \\
\text { motor }\end{array}$ & $81.51 \%$ & $23 \%$ & $65.29 \%$ & $24.67 \%$ & $46.36 \%$ & $20.96 \%$ & 20.987 & $7<0.001$ \\
\hline $\begin{array}{l}\text { months after } \\
\text { physiotherapy and }\end{array}$ & Cognition & $90.51 \%$ & $17.12 \%$ & $82.18 \%$ & $23.44 \%$ & $64.61 \%$ & $23.79 \%$ & 13.236 & $6<0.001$ \\
\hline $\begin{array}{l}\text { conductive } \\
\text { education session }\end{array}$ & $\begin{array}{l}\text { Gross } \\
\text { motor }\end{array}$ & $77.4 \%$ & $17.65 \%$ & $62.53 \%$ & $19.35 \%$ & $43.5 \%$ & $24.28 \%$ & \% 24.011 & $1<0.001$ \\
\hline
\end{tabular}

Table 5. Percentage of improvement in fine motor, cognation and gross motor between group I, group II and group III regards developmental quotient before and after 6 months of physiotherapy and conductive education session.

\begin{tabular}{|c|c|c|c|c|c|c|}
\hline & & \multicolumn{4}{|c|}{$\begin{array}{ll}\text { Developmental quotient Developmental quotient } \\
\text { results before starting } & \text { result } 6 \text { months after } \\
\text { physiotherapy and } & \text { physiotherapy and } \\
\text { conductive education } & \text { conductive education } \\
\text { session } & \text { session }\end{array}$} & \multirow[t]{2}{*}{$\begin{array}{l}\text { Percentage of } \\
\text { improvement }\end{array}$} \\
\hline & & Mean & SD & Mean & SD & \\
\hline \multirow{3}{*}{$\begin{array}{l}\text { Group I } \\
(\leq 12 \mathrm{~ms})\end{array}$} & $\begin{array}{l}\text { Fine } \\
\text { motor }\end{array}$ & 53.74 & 18.53 & 81.51 & 23 & $27.77 \%$ \\
\hline & Cognation & 68.54 & 21.59 & 90.51 & 17.12 & $21.97 \%$ \\
\hline & $\begin{array}{l}\text { Gross } \\
\text { motor }\end{array}$ & 50.89 & 21.66 & 77.4 & 17.65 & $26.51 \%$ \\
\hline \multirow{3}{*}{$\begin{array}{l}\text { Group II } \\
\text { (13 ms - } 23 \mathrm{~ms})\end{array}$} & Fine motor & 52.21 & 19.78 & 65.29 & 24.67 & $13.08 \%$ \\
\hline & Cognation & 64.35 & 20.55 & 82.18 & 23.44 & $17.83 \%$ \\
\hline & $\begin{array}{l}\text { Gross } \\
\text { motor }\end{array}$ & 45.15 & 20.76 & 62.53 & 19.35 & $17.38 \%$ \\
\hline \multirow{3}{*}{$\begin{array}{l}\text { Group III } \\
(\geq 24 \mathrm{~ms})\end{array}$} & Fine motor & 36.94 & 18.29 & 46.36 & 20.96 & $9.42 \%$ \\
\hline & Cognation & 55.06 & 22.11 & 64.61 & 23.79 & $9.55 \%$ \\
\hline & $\begin{array}{l}\text { Gross } \\
\text { motor }\end{array}$ & 35.88 & 17.86 & 43.5 & 24.28 & $7.62 \%$ \\
\hline
\end{tabular}

Percentage of improvement in fine motor in 3 groups; Percentage of improvement in cognation in 3 groups; Percentage of improvement in gross motor in 3 groups.

\section{Discussion}

Cerebral palsy has always been known as a disorder of movement and posture 
resulting from a non-progressive injury to the developing brain [4]. The aim of work of the current study was to study the effect of physiotherapy and conductive education in development of fine, gross motor skills and mental function in the children with cerebral palsy. For this study, 105 children with cerebral palsy less than 4 year selected from outpatient clinic of pediatric neurology department in National Institute for Neuro Motor System.

In the present study (58.03\%) of the children with $\mathrm{CP}$ were males suggesting a male predominance. This result was compatible with the result published in Australian Cerebral Palsy Register (ACPR) where data demonstrated that male s are at higher risk of developing cerebral palsy as $56.4 \%$ of cohort study were males [5]. Males born very preterm also appear to be more vulnerable to white matter injury and intraventricular hemorrhage than females. Experimental studies in adult animals and data from adult patients with stroke indicate that sex hormones such as estrogens provide protection against hypoxic-ischemic injury, and the neonatal brain is also influenced by these hormones, this is why male more liable to cerebral palsy than female [6].

As regards $37 \%$ of our studies case have positive history of consanguinity. Which agreed with [7] who studied that consanguinity and birth deficits in other family members were positively associated with cerebral palsy ( $\mathrm{OR}=4.62 ; 95 \%$ CI: $2.07-10.3$ and $\mathrm{OR}=12.7 ; 95 \%$ CI: $3.13-51.7$ respectively), suggesting a possible genetic link.

In our study we classified the patients into 3 group the first group age was less than 1 years old and second group age ranged from 1 years to 2 years old while the third group was more than 2 year. [8] and [9] suggested that CP could be confirmed at the age of 2 years with sufficient reliability. But another study by [10] supports the choice of 5 years as an appropriate age to ensure that the condition is non-progressive. However, many recent studies confirmed that Cerebral palsy is a clinical diagnosis based on a combination of clinical and neurological signs, diagnosis typically occurs between age 12 and 24 months and early detection of $\mathrm{CP}$ should be considered for early management (early intervention programs) and so for a good prognosis [10] and [11].

Regarding the natal and post natal history the most common risk factors were the history of incubation by respiratory distress which was $51.4 \%$ in group I, $35.3 \%$ in group II, $33.3 \%$ in group III. this is in agreement with [12] who reported the cerebral palsy was diagnosed in six of 257 unventilated newborns (2.3\%), 30 of 320 ventilated newborns without hypocapnia (9.4\%), and 22 of 80 ventilated newborns with hypocapnia (27.5\%), Two additional ventilatory risk factors for disabling cerebral palsy were found hyperoxia and prolonged duration of ventilation, In a multivariate analysis, each of the three ventilator variables independently contributed a 2-to 3-fold increase in risk of disabling cerebral palsy, These risks were additive. Although duration of mechanical ventilation in very low birth weight newborns likely represents severity of illness, both hypocapnia and hyperoxia are largely controlled by ventilatory practice. 
In our study the present of concomitant fits was represented $37.1 \%$ in group I, $11.8 \%$ in group II and 13.9 in group III, this indicated the fits disappear with increase of age. In the study of [13] Forty-one children (25\%) had seizures beyond the neonatal period. Four children had West syndrome, which resolved with treatment. Thirteen children had febrile seizures that they outgrew. Thirty children had focal epilepsy with seizure manifestations and EEG discharges typical of early-onset childhood occipital epilepsy or childhood epilepsy centrotem spikes; 23 have outgrown these seizures. Two children had idiopathic generalized epilepsy; it was ongoing in 1 child. Fourteen children had evolution from 1 epileptic syndrome to another. At last follow-up (median age, 12.7 years; minimum age, 9.7 years), $80 \%$ had not had a seizure for $>2$ years, The electro clinical features of seizure disorders associated with $\mathrm{CP}$ and WMI are those of the age-limited, epileptic syndromes of childhood, with favorable outcome in the majority, The findings have important implications for counseling and drug treatment.

Our study showed that improvement in fine motor was $27.77 \%$ in group I, $13.08 \%$ in group II, $9.42 \%$ in group III and the improvement in cognation was $21.97 \%$ in group I, $17.83 \%$ in group II, 9.55\% in group III after 6 month of 3 session weekly of conductive education, This was a significant improvement in fine motor and cognation in the three group of children with cerebral palsy and the group I was highest percentage in improvement than group II and III this were evident a significant improvement in fine motor and cognation when conductive education program started as early as possible. in the study done by [14] of early developmental intervention programmes that began within the first 12 months of life for infants born before 37 weeks' gestational age follow up by DQ sheet, cognitive outcomes at infancy and at school age was significant, showed a significant effect in favour of early developmental interventions at infancy only.

In the present study the improvement in gross motor was $26.51 \%$ in group I, $17.38 \%$ in group II, $7.62 \%$ in group III after 6 month of 3 session weekly of physiotherapy, this was showed a significant improvement gross motor in the three studied groups of children with cerebral palsy and the group I was highest percentage in improvement than group II and III this concluded a significant improvement in gross motor when start physiotherapy as early as possible.

This agreement with [15] who reported Early Physical Therapy Treatment shows better results on Improvement of GMFCS Score in Different Types of Cerebral Palsy Patients, in his study that conducted on 30 preterm infant after discharge from hospitals, briefed the parents on the objective and contents of physiotherapy treatment, infants will assess in GMFCS, Assessment of the initial performance is follow by the infants receive Early Physiotherapy Intervention for 1 hour daily for 4 year, Regular neurological follow up after 1 year, Second assessment will be done after 1 year and third assessment will be done after 1 year. [16] reported in his study which done in Children with CP in 2015 at Kenyatta National Hospital $(\mathrm{KNH})$ in Kenya, there is a relatively high incidence of children under 6 years with $\mathrm{CP}$, which highlights the need for the provision of 
early intervention and rehabilitation. There was a lack of a multidisciplinary team (MDT) approach to the rehabilitation process for young children with cerebral palsy, and limited techniques were used during therapy.

Furthermore a study done by [17] conducted that early diagnosis begins with a medical history and involves using neuroimaging, standardized neurological, and standardized motor assessments that indicate congruent abnormal findings indicative of cerebral palsy, Clinicians should understand the importance of prompt referral to diagnostic-specific early intervention to optimize infant motor and cognitive plasticity, prevent secondary complications, and enhance caregiver well-being.

On the other hand, a study done by [18] showed lasting benefits of early intervention, this evidence is not sufficient to exclude the value of early intervention. The main reasons for this are the lack of precision in identifying infants for intervention studies and insufficient difference between the interventions offered to the intervention and control group. Although we realize that early identification of all infants with $\mathrm{CP}$ in the general population will not be possible, we propose a research agenda directed at large-scale identification of infants with early signs of $\mathrm{CP}$ and testing of high-intensity, early interventions in which the infant actively participates.

\section{Conclusion}

Significant improvement has in fine motor, cognation and gross motor in group I, II and III after 6 months of regular physiotherapy and conductive education program. Early start physiotherapy and conductive education program gave us better outcome.

\section{Recommendation}

1) Infants who have any risk factor for development of cerebral palsy should be monitored by pediatric neurologist to follow up this infant every 2 months by developmental quotient.

2) If the child diagnosed as cerebral palsy must be started physiotherapy and conductive education program early as possible and regular in this session to reach to the maximum level of improvement.

3) Further studies on large number are needed to determine which early developmental interventions are the most effective in improving cognitive and motor outcomes.

\section{Conflicts of Interest}

The authors declare no conflicts of interest regarding the publication of this paper.

\section{References}

[1] Porretta, D.L. (2017) Cerebral Palsy, Traumatic Brain Injury, and Stroke. In: Winnick, J.P. and Porretta, D.L., Eds., Adapted Physical Education and Sport, 6th Edi- 
tion, Human Kinetics, Champaign, 217-290.

[2] Goosey-Tolfrey, V.L. and Mason, B.S. (2017) Enhancing Wheelchair Sport Performance. In: Winnick, J.P. and Porretta, D.L., Eds., Adapted Physical Education and Sport, 6th Edition, Human Kinetics, Champaign, 565-584.

[3] Lavay, B.W. (2017) Perceptual-Motor Development. In: Winnick, J.P. and Porretta, D.L., Eds., Adapted Physical Education and Sport, 6th Edition, Human Kinetics, Champaign, 391-406.

[4] Wimalasundera, N. and Stevenson, V.L. (2016) Cerebral Palsy. Practical Neurology, 16, 184-194. https://doi.org/10.1136/practneurol-2015-001184

[5] EL-Mancy, S. (2010) Study of Pattern of Cerebral Palsy among Children Attending the Pediatric Neurology Clinic of Alexandria University Children's Hospital. Master Thesis, Faculty of Medicine, Alexandria University, Alexandria.

[6] Michael, V. and Henrik, H. (2006) Sex and the Pathogenesis of Cerebral Palsy. Developmental Medicine \& Child Neurology, 49, 74-78. https://doi.org/10.1017/S0012162207000199.x

[7] Daher, S. and El-Khairy, L. (2014) Association of Cerebral Palsy with Consanguineous Parents and Other Risk Factors in a Palestinian Population. Eastern Mediterranean Health Journal, 20, 459-468. https://doi.org/10.26719/2014.20.7.459

[8] Paneth, N., Hong, T. and Korzeniewski, S. (2006) The Descriptive Epidemiology of Cerebral Palsy. Clinics in Perinatology, 33, 251-267. https://doi.org/10.1016/j.clp.2006.03.011

[9] Voss, W., Neubauer, A.P., Wachtendorf, M., Verhey, J.F. and Kattner, E. (2007) Neurodevelopment Outcome in Extremely Low Birth Weight Infant: What Is the Minimum Age for Reliable Developmental Prognosis? Acta Paediatrica, 96, 342-347. https://doi.org/10.1111/j.1651-2227.2006.00130.x

[10] Granild-Jensen, J.B., Rackauskaite, G. and Flachs, E.M. (2015) Predictors for Early Diagnosis of Cerebral Palsy from National Registry Data. Developmental Medicine \& Child Neurology, 57, 931-935. https://doi.org/10.1111/dmcn.12760

[11] Hubermann, L., Boychuck, Z., Shevell, M. and Majnemer, A. (2016) Age at Referral of Children for Initial Diagnosis of Cerebral Palsy and Rehabilitation: Current Practices. Journal of Child Neurology, 31, 364-369. https://doi.org/10.1177/0883073815596610

[12] Michael, C.P., Lorenz, J.M., Jetton, J.R. and Paneth, N. (2001) Hypocapnia and Other Ventilation-Related Risk Factors for Cerebral Palsy in Low Birth Weight Infants. Pediatric Research, 50, 712-719. https://doi.org/10.1203/00006450-200112000-00014

[13] Cooper, M.S., Mackay, M.T., Fahey, M., Reddihough, D., Reid, S.M., Williams, K. and Harvey, A.S. (2017) Seizures in Children with Cerebral Palsy and White Matter Injury. Pediatrics, 139, e20162975. https://doi.org/10.1542/peds.2016-2975

[14] Spittle, A., Orton, J., Anderson, P.J., Boyd, R. and Doyle, L.W. (2015) Early Developmental Intervention Programmes Provided Post Hospital Discharge to Prevent Motor and Cognitive Impairment in Preterm Infants. Cochrane Database of Systematic Reviews, No. 11, CD005495. https://doi.org/10.1002/14651858.CD005495.pub4

[15] Patel, I.A. (2017) Effect of Early Physical Therapy Treatment on Improvement of GMFCS Score in Different Type of Cerebral Palsy Patients in Selected Urban Community Ahmedabad, Gujarat. Indian Journal of Physiotherapy and Occupational Therapy-An International Journal, 11, 101-103.

https://doi.org/10.5958/0973-5674.2017.00082.X 
[16] Ngota, D.O. (2018) The Process of Rehabilitation for 0-6 Year Old Children with Cerebral Palsy at Kenyatta National Hospital, Kenya.

[17] Novak, I., Morgan, C. and Adde, L. (2017) Early, Accurate Diagnosis and Early Intervention in Cerebral Palsy: Advances in Diagnosis and Treatment. JAMA Pediatrics, 171, 897-907. https://doi.org/10.1001/jamapediatrics.2017.1689

[18] Herskind, A., Greisen, G., Nielsen, J.B., et al. (2014) Early Identification and Intervention in Cerebral Palsy. Developmental Medicine \& Child Neurology, 57, 29-36. https://doi.org/10.1111/dmcn.12531 